DOI: $10.2478 / \mathrm{v} 10014-008-0004-7$

Agrovoc descriptors: biological control, natural enemies, beneficial organisms,

biological control agents, insect nematodes, nematoda, steinernema, introduced varieties

Agris category codes: $\mathrm{H} 10$

University of Ljubljana

Biotechnical Faculty

Department of Agronomy

COBISS Code 1.01

\title{
Entomopathogenic nematode Steinernema feltiae (Filipjev) (Rhabditida: Steinernematidae) recorded for the first time in Slovenia
}

\author{
Žiga LAZNIK ${ }^{1}$, Timea TÓTH², Tamás LAKATOS ${ }^{3}$, Stanislav TRDAN ${ }^{4}$
}

Delo je prispelo 27. decembra 2007, sprejeto 31. marca 2008.

Received December 27, 2007; accepted March 31, 2008.

\section{ABSTRACT}

In Slovenia only recently entomopathogenic nematodes were recorded for the first time. In the beginning of 2007, the presence of Steinernema affine was confirmed. During the further investigations in the same year Steinernema feltiae was recorded on the arable field near Cerknica. In the previous year this field was planted with chicory. In Slovenia, until now the entomopathogenic nematodes had a status of an exotic agents and their use was allowed only in the laboratory experiments. We expect that in Slovenia the use of these biological agents against insect pests will become important alternative to insecticides as it is known in many other countries of the world.

Key words biological control, entomopathogenic nematodes, exotic agents, Slovenia, Steinernema affine, Steinernema feltiae

\section{IZVLEČEK}

\section{ENTOMOPATOGENA OGORČICA Steinernema feltiae (Filipjev) (Rhabditida:} Steinernematidae) PRVIČ UGOTOVLJENA V SLOVENIJI

V Sloveniji so bile entomopatogene ogorčice prvič ugotovljene šele nedavno. $V$ začetku leta 2007 je bila potrjena zastopanost vrste Steinernema affine, med nadaljnjimi raziskavami $v$ istem letu pa je bila na njivi v bližini Cerknice najdena tudi ogorčica Steinernema feltiae. Na omenjenem zemljišču so leto prej pridelovali radič. Doslej so imele entomopatogene ogorčice $v$ Sloveniji status tujerodnih organizmov, njihova uporaba pa je bila dovoljena le v laboratorijskih poskusih. Pričakujemo, da bo v Sloveniji uporaba omenjenih naravnih sovražnikov škodljivih žuželk postala pomembna alternativa insekticidom, kar je sicer že znano $v$ številnih drugih državah sveta.

Ključne besede biotično varstvo, entomopatogene ogorčice, Slovenija, Steinernema affine, Steinernema feltiae, tujerodni organizmi,

\footnotetext{
${ }^{1}$ Young researcher, B. Sc., Jamnikarjeva 101, SI-1111 Ljubljana, email:ziga.laznik@bf.uni-lj.si

${ }^{2}$ Ph.D student, M. Sc., Vadastag 2, H-4244 Újfehértó, Hungary

${ }^{3}$ Ph. D, Vadastag 2, H-4244 Újfehértó, Hungary

${ }^{4}$ Assist. Prof., Ph. D, Jamnikarjeva 101, SI-1111 Ljubljana
} 
In Slovenia, the first research on entomopathogenic nematodes (EPNs) was carried out in 2004. Because in Slovenia EPNs still have a status of an exotic agents, all earlier researches were limited merely to laboratory experiments. The aim of previous research was to study the efficacy of the nematodes against foliar pests (Laznik et al., 2007).

EPNs from the families Steinernematidae and Heterorhabditidae are important pathogens of insects. These soil organisms are mutually associated with bacteria from genus Photorhabdus Boemare, Akhurst and Mourant (genus Heterorhabditis) and bacteria from genus Xenorhabdus Thomas and Poinar (genus Steinernema) (Burnell and Stock, 2000). After infection, the symbiotic bacteria are released into the insect hemocoel, causing septicemia and death of the insect in 24 to 72 hours (Forst and Clarke, 2002).

Because of broad spectrum of target hosts from the class Insecta, their application as a way of biological control of plants against pests is so far very well known (Kaya and Gaugler, 1993). Application of EPNs in biological control was traditionary engaged in controlling soil pests until some years ago (Ishibashi and Choi, 1991). Results from research in the last two decades indicate also their potential against foliar pests, but only under special conditions (Arthurs et al., 2004). Poorer efficacy of EPNs in controlling foliar pest is a consequence of unsuitable (too low) moisture (Lello et al., 1996), exposure to extreme temperatures (Grewal et al., 1994), and ultraviolet radiation (Gaugler and Boush, 1978). These factors are known as crucial for nematodes survival (Kaya, 1990). For this reason the efficacy of foliar pests with EPNs in the open is therefore often worser as expected, although predecessor laboratory tests shows rather better efficacy (Buitenhuis and Shipp, 2005).

Numerous other research showed that at lower concentration EPNs are much more efficient in controlling preadult stages of insects from order Coleoptera (Ansari et al., 2003). Similar findings were also confirmed with controlling insects from other orders; Thysanoptera (Premachandra et al., 2003), Lepidoptera (Yakir-Ben et al., 1998), Diptera (Willmott et al., 2002) and some others. In majority of cases it was about the larvae, which life cycle is predominantly linked with soil and easily attacked by EPNs.

In October 2007, we examined 77 soil samples on the occurrence of EPNs in Slovenia. The soil samples were taken in Notranjska region of Slovenia, which is the south central part of the country. We used "Galleria bait method ", which is the most frequently used method of EPNs detection from soil. After the death of wax moth (Galleria mellonella [Linnaeus]) larvae, we dried cadavers for 12 days and put them in so called "White trap« (Bedding and Akhurst, 1975) to separate the nematodes from death larvae. With the received suspension we infected artificialy larvae of wax moth again. Following procedure contained the use of centrifuge and $5 \%$ concetration of sodium hypoclorate. The aim of this process was to get infective juveniles from the suspension. We confirmed the presence of nematodes in $9.09 \%$ of samples. Only 1 positive sample, B30 (taken on the chicory arable field near Cerknica (SW Slovenia, $45^{\circ} 48^{\prime} \mathrm{N}$, $14^{\circ} 22^{\prime} \mathrm{E}, 572 \mathrm{~m}$ alt.) was identified to this time. 
To confirm the identification of isolated nematodes from larvae of wax moth, a selected sample was analysed by molecular biological approach. Genomic DNA was extracted from individual nematodes and PCR was performed to multiply ITS region using primers TW81 and AB28 after Hominick et al. (1997). PCR product were reisolated from 1\% TAE-buffered agarose gel using E.Z.N.A. Gel Extraction Kit (Omega Bio-Tek, USA) (Fig. 1). Reisolated sample was sequenced in the laboratory of Agricultural Biotechnology Centre in Gödöllö, Hungary. Sample DNA sequence was compared to sequences of species Steinernema using BLAST search in National Centre for Biotechnology Information (NCBI) web site (www.ncbi.nlm.nih.gov). The sequences producing significant alignments and at least $99 \%$ identity were derived from Steinernema feltiae: GenBank Accession No. DQ310469 and AF121050 (Nguyen et al., 2001) (Fig. 2).

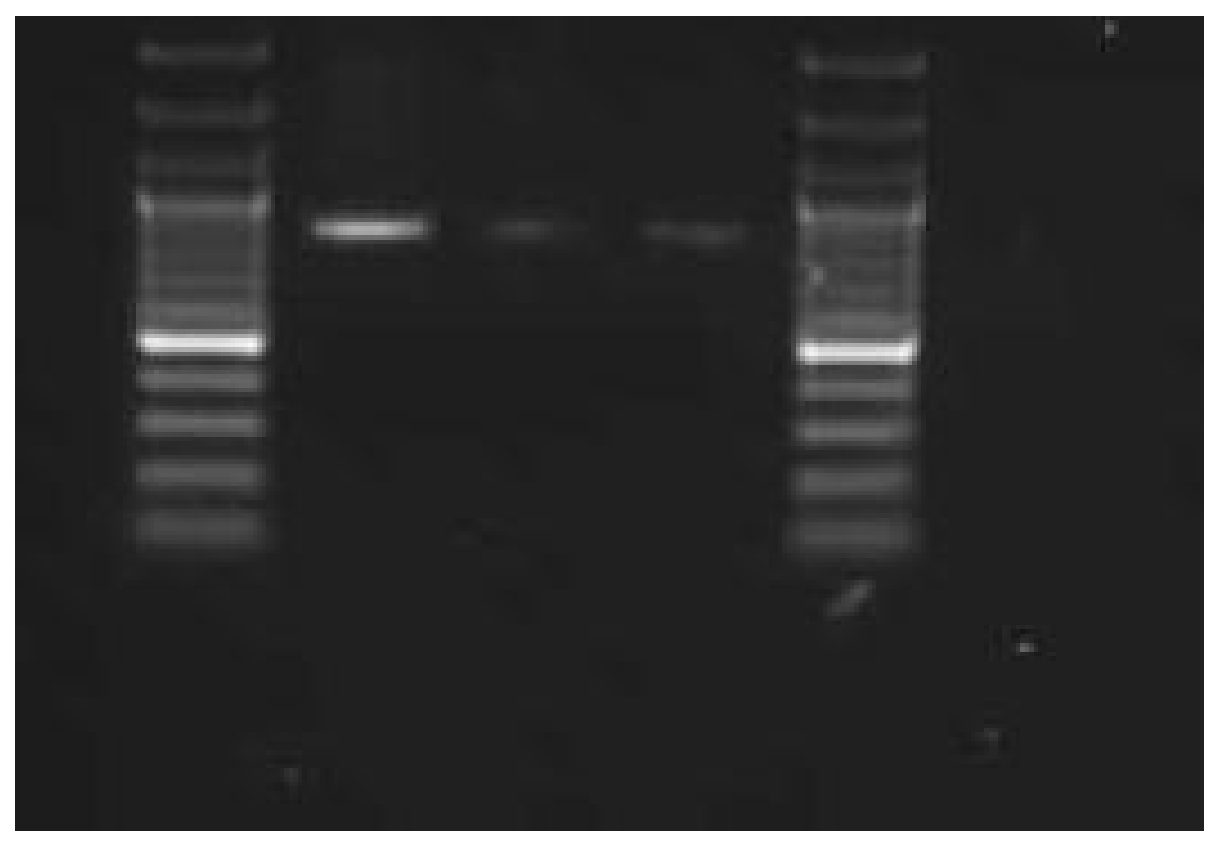

Figure 1: $1 \%$ TAE buffered agarose gel, in the $1^{\text {st }}$ and $5^{\text {th }}$ lanes: GeneRuler $100 \mathrm{bp}$ DNA Ladder Plus (Fermentas), in the $2^{\text {nd }}$ lane: PCR product of our sample B30, using the primer pair specified in the text, $3^{\text {rd }}$ lane: PCR product of sample B49, $4^{\text {th }}$ lane: PCR product of sample 3162 . The two most strength fragment in the ladder are 500 and 1000 bps length.

\section{$4 \quad$ DISCUSSION}

Genetic studies proved that the nematode species is Steinernema feltiae Filipjev (1934) (Fig. 3). The ITS1-5.8S-ITS2 region, including the partial $18 \mathrm{~S}$ and $28 \mathrm{~S}$ rDNA genes (flanked by above primers) of Slovenian isolate B30 is 742bp long. 
BLAST searches (Altschul et al., 1990) in GenBank showed that Slovenian isolate B30 has a high similarity (99\%) with those sequences available for S. feltiae populations (e.g. accession numbers DQ310469 and AF121050). Sequence of other species from feltiae group, namely $S$. litorale was obtained from GenBank searches that exhibited a lesser degree of similarity with the Slovenian isolate and other $S$. feltiae populations (e.g. accesion number AB243441) (Fig. 3). The present study constitutes the first report of $S$. feltiae in Slovenia. S. feltiae has a wide distribution in temperate regions, being one of the most common species found in Europe, and in many other parts of the world (for a detailed EPN species distribution see Hominick, 2002).

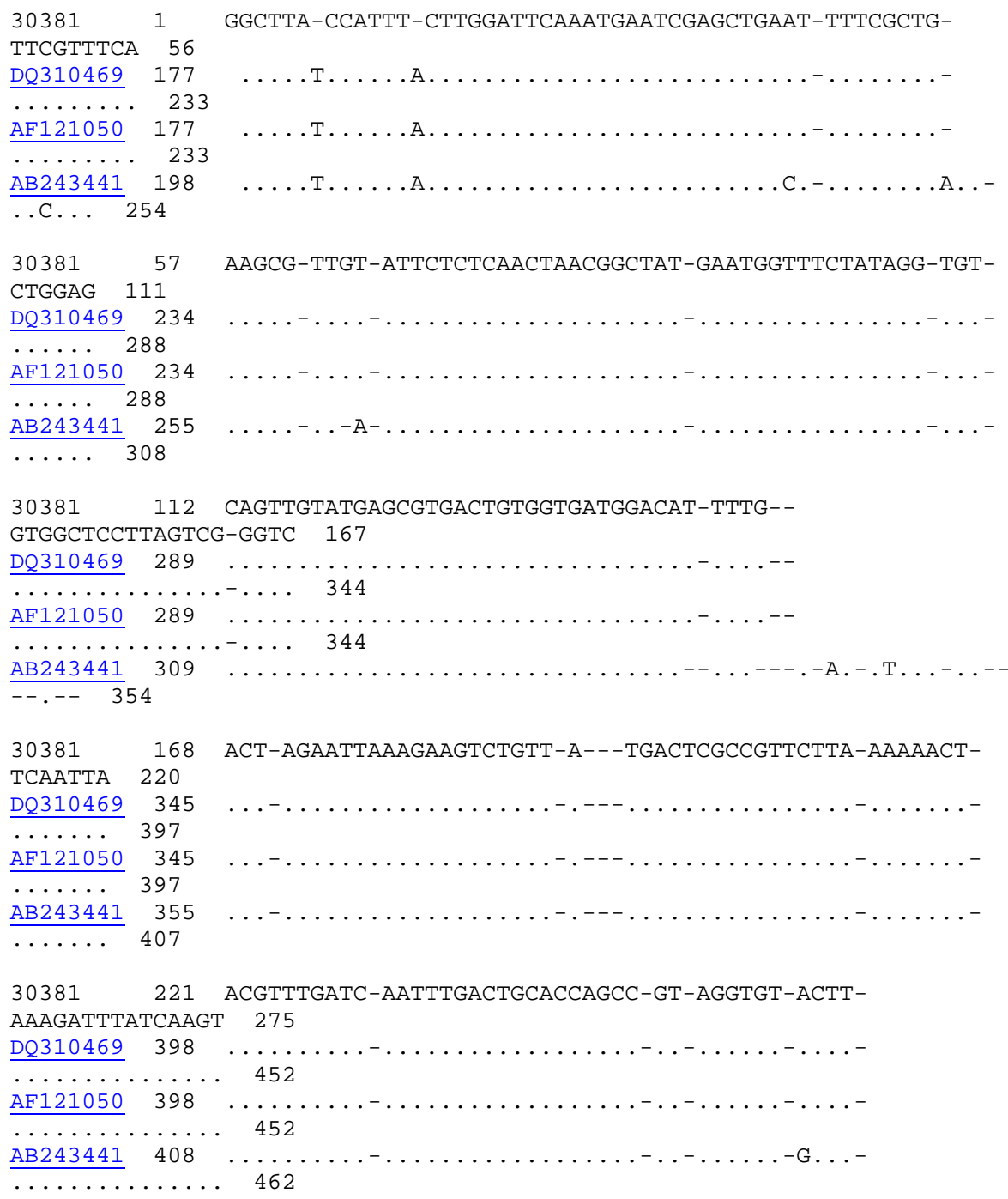




\begin{tabular}{|c|c|c|}
\hline $\begin{array}{l}30381 \\
\text { CCGTTATTT }\end{array}$ & $\begin{array}{c}276 \\
334\end{array}$ & CTTGTCGGTGGATCACTCGGTTCGTAGTTCGATGAAAAACGGGGCAAAAA- \\
\hline DQ310469 & 453 & \\
\hline & 511 & \\
\hline AF121050 & 453 & \\
\hline & 511 & \\
\hline AB243441 & 463 & \\
\hline$\overline{\ldots \ldots}$. & 521 & \\
\hline 30381 & 335 & GGCGTGAATTGCAGACATATTGAACGCTAAAATTTTGAACGCAAATGG - CAC - \\
\hline TATCAGG & 392 & \\
\hline$\underline{D Q 310469}$ & 512 & \\
\hline & 569 & \\
\hline AF121050 & 512 & $\ldots$ \\
\hline$\ldots 5$ & 569 & \\
\hline$\underline{A B 243441}$ & 522 & $\ldots \ldots \ldots \ldots \ldots-\ldots-$ \\
\hline$\ldots \ldots 5$ & 579 & \\
\hline 30381 & 393 & TTTATATCTGTTAGTATGTTTGGTTGAGGGTCGATTAATTCGTAACCTGCA- \\
\hline GTCTGCTG & 451 & \\
\hline DQ310469 & 570 & $\cdots$ \\
\hline$\ldots \ldots$ & 628 & \\
\hline AF121050 & 570 & $\cdots$ \\
\hline$\ldots \ldots$ & 628 & \\
\hline AB243441 & 580 & $\ldots \ldots \ldots \ldots \ldots \ldots \ldots \ldots$ \\
\hline$\overline{\ldots \ldots}$ & 638 & \\
\hline 30381 & 452 & TGACTGTTTTTT - CGATTAGTTATTTG - G - TT - - T - TT - - TT - A - \\
\hline TCGAGTACCT & TTTT - T & 500 \\
\hline DQ310469 & 629 & $\ldots \ldots-\ldots \ldots \ldots \ldots \ldots-, \ldots-{ }_{-1}-\ldots-,-$ \\
\hline & $\ldots$. & 677 \\
\hline$\frac{\text { AF121050 }}{\ldots \ldots}$ & 629 & 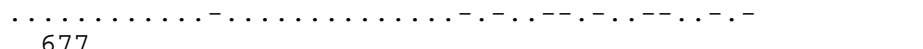 \\
\hline AB243441 & 639 & $\ldots \ldots \ldots \ldots-\ldots \ldots \ldots, \ldots-A-\ldots-C-A-\ldots---$ \\
\hline$\cdots$ & - - & 684 \\
\hline 30381 & 501 & - GGAATGTGAATT - - T - - GATTGTCTAATTCGTTTCCTAATCG - - AAA - \\
\hline CGAGCTATTT & TT 55 & \\
\hline DQ310469 & 678 & $--\ldots$ \\
\hline$\ldots \ldots \ldots$ & . 725 & \\
\hline AF121050 & 678 & \\
\hline$\ldots \ldots \ldots$ & . . 725 & \\
\hline AB243441 & 685 & $\ldots \ldots \ldots-. T-\ldots \ldots \ldots \ldots \ldots \ldots \ldots \ldots-\ldots-$ \\
\hline$\ldots \ldots \ldots A$ & A. $73 \xi$ & \\
\hline 30381 & 553 & TTA- TTTCTGTGCAATGTATTTTTGGTGTTTCGGCGTT - TTTCTTGCCGACTGA- \\
\hline T-TGG 608 & & \\
\hline DQ310469 & 730 & . \\
\hline$-\ldots 785$ & & \\
\hline AF121050 & 730 & \\
\hline$-\ldots 785$ & & \\
\hline AB243441 & 739 & C........, \\
\hline$. G \ldots-793$ & & \\
\hline 30381 & 609 & TACAAACTTAACAGT - TCGTATATTTTTCAGAATTT - TTCAGA - GGCCCTTACA - \\
\hline A-TA- 662 & 2 & \\
\hline$\frac{\mathrm{DQ} 310469}{. . .-839}$ & 786 & 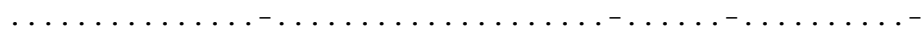 \\
\hline $\begin{array}{ll}-1 .-839 \\
\text { AF } 121050\end{array}$ & 786 & \\
\hline$-\ldots-839$ & & \\
\hline AB243441 & 794 &.- A... \\
\hline
\end{tabular}




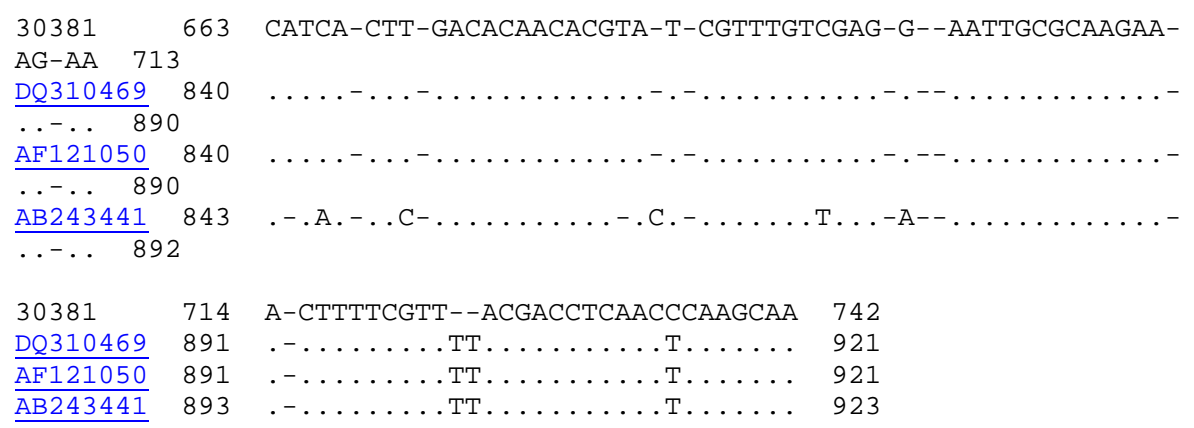

Figure 2: Multiple sequence alignment of the ITS rDNA region (including partial fragments of the $18 \mathrm{~S}$ and $28 \mathrm{~S}$ rDNA genes) of 4 Steinernema species. Code 30381 correspond to the Slovenian isolate of Steinernema feltiae (B30). Codes DQ310469 and AF121050 are Steinernema feltiae strains from Russia and USA. Code AB243441 correspond to Steinernema litorale strain from Japan.

We can place mentioned species into »feltiae group« of nematodes from genus Steinernema (Nguyen, 2006); for infective juveniles it is known that they are between 1000 and $700 \mu \mathrm{m}$ long (Fig. 3). This nematode lives in symbiosis with bacterium Xenorhabdus bovienii (Poinar, 1988). The nematode was first recorded in 1934, and its appliable value in biological control of insect pests is well known (Ebssa, 2001). Some researchers reported that S. feltiae, S. intermedium (or C1) and S. affine like to appear on agricultural land (Sturhan, 1996). In Europe, the occurrence of $S$. feltiae was up to now confirmed in Austria, Belgium, Great Britain, Czech Republic, Denmark (original), Estonia, Finland, France, Germany, Greece, Hungary, Ireland, Italy, Poland, Slovakia, Spain, Sweden, Switzerland, Netherlands, Norway, Ukraine, Bolgaria and Portugal (Hominick, 2002).

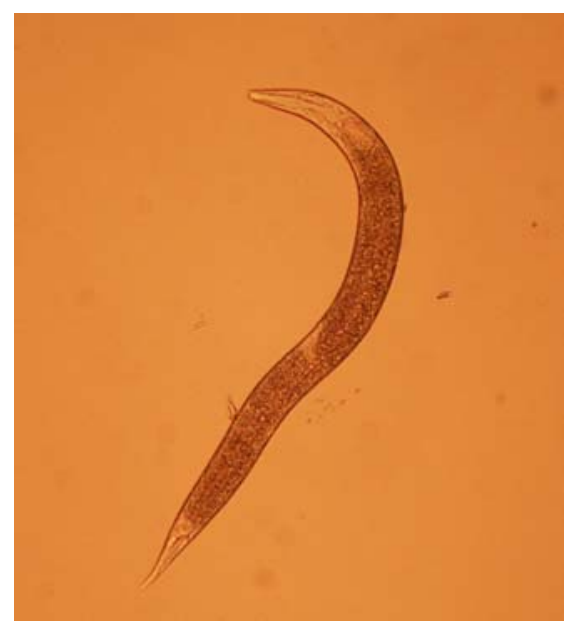

Figure 3: Infective juvenile of Steinernema feltiae from sample B30. 
Up to the present EPNs in Slovenia had a status of exotic agents and their efficacy against different insect pests was performed merely in laboratory experiments; Colorado potato beetle (Leptinotarsa decemlineata [Say]), greenhouse whitefly (Trialeurodes vaporariorum [Westwood]), western flower thrips (Frankliniella occidentalis [Pergande]) (Perme, 2005), sawtoothed grain beetle (Oryzaephilus surinamensis [L.]) and granary weevil (Sitophilus granarius [L.]) (Trdan et al., 2006) and flea beetles (Phyllotreta spp.) (Trdan et al., 2008). The results of these experiments confirmed already known facts that - in optimal conditions - EPNs represent very effective agents to control insect pests. After the first record of Steinernema feltiae in Slovenia, we expect that the use of these biological agents against insect pest will become important alternative to insecticides. These will be especially desired against the pests which is not easy to control with insecticides due to their massive occurrence in the period of harvesting, against the pests which are resistant to insecticides etc. B30 strain of S. feltiae will be in the future experiments used against different agricultural pests under laboratory conditions as well as in the experiments taken outside.

\section{ACKNOWLEDGEMENTS}

This work is a part of program Horticulture No P4-0013-0481 granted by Slovenian Ministry of Higher Education, Science and Technology.

\section{REFERENCES}

Altschul S.F., Gish W., Miller W., Myers E.W., Lipman D.J. 1990. Basic local alignment search tool. J. Mol. Biol. 215: 403 - 410.

Ansari M.A., Tirry L., Moens M. 2003. Entomopathogenic nematodes and their symbiotic bacteria for the biological control of Hoplia philanthus (Coleoptera: Scarabaeidae). Biol. Control 28: 111-117.

Arthurs S., Heinz K.M., Prasifka J.R. 2004. An analysis of using entomopathogenic nematodes against above-ground pests. Bull. Entomol. Res. 94: 297-306.

Bedding R.A., Akhurst R.J. 1975. Simple technique for the detection of insect parasitic rhabditid nematodes in soil. Nematologica 21: 109-110.

Buitenhuis R., Shipp J.L. 2005. Efficacy of entomopathogenic nematode Steinernema feltiae (Rhabditida: Steinernematidae) as influenced by Frankliniella occidentalis (Thysanoptera: Thripidae) developmental stage and host plant stage. J. Econ. Entomol. 98: 1480-1485.

Burnell A.M., Stock S.P. 2000. Heterorhabditis, Steinernema and their bacterial symbionts lethal pathogens of insects. Nematology 2: 31-42.

Ebssa L., Borgemeister C., Berndt O., Poehling H.-M. 2001. Efficacy of entomopathogenic nematodes against soil-dwelling life stages of western flower thrips, Frankliniella occidentalis (Thysanoptera:Thripidae). J. Invert. Pathol. 78: 119-127.

Filipev I.N. 1934. Eine newe art der gattung Neoaplectana Steiner nebst Bemerkungen uber die systematishe sellung der letzteren. Magasin de parasitologie de l'Institut zoologique des Sciences de l' USSR. IV. 1934229-240. 
Forst S., Clarke D. 2002. Bacteria-nematode symbiosis. In: Gaugler R (ed) Entomopathogenic Nematology. CABI Publishing, Wallingford, pp. 57-77.

Gaugler R., Boush G.M. 1978. Effects of ultraviolet radiation and sunlight on the entomopathogenous nematode, Neoaplectana carpocapsae. J. Invertebr. Pathol. 32: 291-296.

Grewal, P.S., Selvan S., Gaugler R. 1994. Thermal adaptation of entomopathogenic nematodes: niche breadth for infection, establishment, and reproduction. J. Therm. Biol. 19: 245-253.

Hominick W.M., Briscoe B.R., del Pino F.G., Heng J., Hunt D.J., Kozodoy E., Mracek Z., Nguyen K.B., Reid A.P., Spiridonov S., Stock P., Sturhan D., Waturu C., Yoshida M. 1997. Biosystematics of entomopathogenic nematodes: current status, protocols and definitions. J. Helminthol. 71: 271-298.

Hominick W.M. 2002. Biogeography. In: Gaugler R (ed) Entomopathogenic Nematology. CABI Publishing, Wallingford, pp. 115-143.

Ishibashi N., Choi D.-R. 1991. Biological control of soil pests by mixed application of entomopathogenic and fungivorous nematodes. J. Nematology 23: 175-181.

Kaya H.K. 1990. Soil ecology. In: Gaugler R and Kaya HK (eds.) Entomopathogenic Nematodes in Biological Control, CRC Press, Florida, pp. 93-115.

Kaya H.K., Gaugler R. 1993. Entomopathogenic nematodes. Annu. Rev. Entomol. 38: 181206.

Laznik Ž., Tóth T., Lakatos T., Trdan S. 2007. First record of entomopathogenic nematodes in Slovenia and perspectives of their use. In: 11th European meeting [of the] IOBC/WPRS Working group "Insect pathogens and insect parasitic nematodes" in association with COST 862 Bacterial toxins for insect control, Alès, Gard, France, June 3rd-7th, From laboratory to field key points. pp. 79-80.

Lello E.R., Patel M.N., Mathews G.A., Wright D.J. 1996. Application technology for entomopathogenic nematodes against foliar pests. Crop protection 15: 567-574.

Nguyen K.B. 2006. Entomopathogenic Nematodes. Entomology and Nematology Department (31. jan. 2006) http://kbn.ifas.ufl.edu/kbnstein.htm (21.11.2007)

Nguyen K.B., Maruniak J., Adams B.J. 2001. The Diagnostic and Phylogenetic Utility of the rDNA Internal Transcribed Spacer Sequences of Steinernema. J. Nematol. 33: 73-82.

Perme S. 2005. Testing the efficacy of entomopathogenic nematodes (Rhabditida) against foliar pests of vegetables. M.Sc. Thesis, University of Ljubljana, Biotechnical Faculty, Department of Agronomy, pp.89 [Slovenian]

Poinar G.O. 1988. Redescription of Neoaplectana affinis Bovien (Rhabditida: Steinernematidae). Rev. Nematol. 11: 143-147.

Premachandra W.T.S.D., Borgemeister C., Berndt O., Ehlers R.-U., Poehling H.-M. 2003. Laboratory bioassays of virulence of entomopathogenic nematodes against soilinhabiting Frankliniella occidentalis Pergande (Thysanoptera: Thripidae). Nematology 5: 539-547.

Sturhan D. 1996. Seasonal occurrence, horizontal and vertical dispersal of entomopathogenic nematodes in a field. Mitt. Biol. Bundesanst. Land. Forstwirtsch. 317: 35-45.

Trdan S., Vidrih M., Valič N. 2006. Activity of four entomopathogenic nematode species against young adults of Sitophilus granarius (Coleoptera: Curculionidae) and 
Oryzaephilus surinamensis (Coleoptera: Silvanidae) under laboratory conditions. J. Plant. Dis. Prot. 113: 168-173.

Trdan S., Vidrih M., Valič N., Laznik Ž. 2008. Impact of entomopathogenic nematodes on adults of Phyllotreta spp. (Coleoptera: Chrysomelidae) under laboratory conditions. Acta Agric. Scand., B Soil Plant. Sci. 58: 169-175.

Yakir-Ben D., Efron D., Chen M., Glazer I. 1998. Evaluation of Entomopathogenic Nematodes for Biocontrol of the European Corn Borer, Ostrinia nubilalis, on Sweet Corn in Israel. Phytoparasitica 26:1-8.

Willmott D.M., Hart A.J., Long S.J., Richardson P.N., Chandler D. 2002. Susceptibility of cabbage root fly Delia radicum, in potted cauliflower (Brassica oleracea var. botrytis) to isolates of entomopathogenic nematodes (Steinernema and Heterorhabditis spp.) indigenous to the UK. Nematology 4:965-970. 